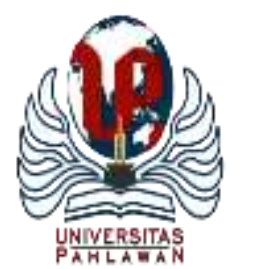

Edukatif : Jurnal Ilmu Pendidikan Volume 3 Nomor 5 Tahun 2021 Halm 3163 - 3172

EDUKATIF: JURNAL ILMU PENDIDIKAN

Research \& Learning in Education

https:/ledukatif.org/index.php/edukatif/index

\title{
Pengaruh Model Pembelajaran Project Based Learning terhadap Peningkatan Motivasi Belajar dan Kerja Sama Siswa dan Orang Tua di Era Pandemi
}

\author{
Indradi Kartika Sukmana ${ }^{1 凶}$, Nur Amalia ${ }^{2}$ \\ Universitas Muhammadiyah Prof. Dr. Hamka, Indonesia ${ }^{1,2}$ \\ E-mail : ․ㅡdradik15@gmail.com ${ }^{1}, \underline{\text { nur21amalia@gmail.com }}^{2}$
}

\begin{abstract}
Abstrak
Model Project Based Learning adalah salah satu model yang banyak dipakai oleh para pendidik pada kegiatan Belajar Dari Rumah seperti sekarang. Kegiatan Belajar Dari Rumah dengan menggunakan model Project Based Learning dianggap mampu menjadi pengaruh dalam peningkatan motivasi belajar peserta didik sekaligus kerja sama antara peserta didik dan orang tua. Penelitian ini bermaksud untuk mengetahui pengaruh dari model Project Based Learning yang diterapkan selama kegiatan belajar dari rumah di kelas 4 SDN Grogol Utara 16 Jakarta Selatan terhadap peningkatan motivasi belajar dan kerja sama peserta didik dengan orang tuanya. Jenis penelitian ini merupakan penelitian kualitatif dengan rancangan penjelasan deskriptif. Pengumpulan data dalam penelitian melalui lembar pengisian kuesioner dalam google form yang disebarkan melalui grup whatsapp kelas. Hasil yang diperoleh berdasarkan data yang dianalisis kemudian ditarik kesimpulannya adalah bahwa model Project Based Learning memiliki pengaruh terhadap meningkatnya motivasi belajar peserta didik sekaligus kerja sama antara peserta didik dengan orang tuanya.Hal tersebut dibuktikan oleh beberapa jawaban dari kuesioner yang diisi oleh orang tua dan peserta didik.
\end{abstract}

Kata Kunci: Project Based Learning, Belajar Dari Rumah (BDR), Motivasi belajar, Kerja sama.

\begin{abstract}
The Project Based Learning model is one model that is widely used by educators in Learning From Home activities as it is now. Learning From Home Activities using the Project Based Learning model is considered capable of being an influence in increasing students' learning motivation as well as cooperation between students and parents. This study intends to determine the effect of the Project Based Learning model applied during the Learning From Home activity in grade 4 SDN Grogol Utara 16 South Jakarta on increasing students' learning motivation and collaboration between students and their parents. This type of research is a qualitative research with a descriptive explanation design. Collecting data in the study through questionnaires filled out in Google Forms distributed through the class WhatsApp group. The results obtained based on the analyzed data and then concluded that the Project Based Learning model has an influence on increasing students' learning motivation as well as cooperation between students and their parents. This is evidenced by several answers from questionnaires filled out by parents and students.
\end{abstract}

Keywords: Project Based Learning, Learning From Home (BDR), learning motivation, Cooperation.

Copyright (c) 2021 Indradi Kartika Sukmana, Nur Amalia

Corresponding author

Email : indradik15@gmail.com

DOI : $\quad$ https://doi.org/10.31004/edukatif.v3i5.1068

ISSN 2656-8063 (Media Cetak)

ISSN 2656-8071 (Media Online)

Edukatif : Jurnal Ilmu Pendidikan Vol 3 No 5 Tahun 2021 p-ISSN 2656-8063 e-ISSN 2656-8071 


\section{PENDAHULUAN}

Proses pembelajaran barangkali menjadi suatu perhatian khusus bagi para pemerhati pendidikan. Mengacu pada kebijakan pemerintah yang terdapat dalam surat edaran dari Kementerian Pendidikan dan Kebudayaan nomor 4 yang diterbitkan pada Tahun 2020. Keputusan tersebut menjadi sorotan bagi kita terhadap dunia pendidikan yang sampai saat ini sudah berusia satu tahun lebih mengharuskan pembelajaran konvensional menjadi pembelajaran daring. Hal tersebut menjadi salah satu dari sekian banyak dampak dari era pandemi seperti sekarang. Belajar Dari Rumah (BDR) adalah salah satu perubahan yang memaksa pendidikan kita untuk menjadi upaya untuk terus mewujudkan cita-cita bangsa, yaitu mencerdaskan kehidupan bangsa, namun juga sebagai upaya mencegah kengerian yang ditimbulkan oleh pandemi Covid-19.

Respon beragam muncul dari segala lapisan masyarakat yang menyoroti perubahan proses pembelajaran daring ini. Mulai dari respon yang pro dan yang kontra, semua tentu mempunyai alasannya masing-masing. Banyak yang menilai bahwa pembelajaran secara daring ini memiliki berbagai keuntungan. Keuntungankeuntungan tersebut salah satunya karena pemanfaatan teknologi itu sendiri. Peserta didik diharapkan dapat mengeksplorasi lebih dalam atas apa yang dipelajarinya dari internet, hingga pembelajaran yang efektif karena hanya menggunakan gawai. Terlepas dari keuntungan-keuntungan yang ada, tentunya akan ada juga kekurangan-kekurangan dari proses pembelajaran ini. Timbul kekhawatiran yang berlebih dari setiap insan mengenai kebijakan pembelajaran ini. Protes-protes tentang bagaimana kondisi teknologi yang masih belum memadai di setiap wilayah, hingga bagaimana cara peserta didik belajar tanpa dampingan seorang pendidik hingga bagaimana evaluasi yang harus dilakukan oleh seorang pendidik dalam menilai peserta didik yang tidak diawasi secara tatap muka itu.

Permasalahan tersebut menuntut kita untuk harus beradaptasi dengan situasi sekarang ini. Apabila proses pembelajaran konvensional pada umumnya menjadikan pendidik sebagai pengajar sekaligus penilai peserta didik. Maka proses Belajar Dari Rumah (BDR) ini mengharuskan para orang tua aktif dalam melakukan pendampingan dan pengajaran untuk anaknya. Hal tersebut harus diusahakan dilakukan oleh orang tua secara maksimal. Karena anak akan kesulitan apabila menjalani proses pembelajaran secara mandiri di rumah. Untuk itu kesediaan orang tua dalam mendampingi anak Belajar Dari Rumah (BDR) dinilai menjadi keharusan, tetapi kita juga ketahui bahwa tidak semua orang tua bisa dan mampu mendampingi anak dalam melakukan kegiatan Belajar Dari Rumah (BDR). Masih banyak orang tua yang tidak sempat mendampingi anaknya sebab mereka masih bekerja secara langsung, meskipun sebagian pekerjaan diharuskan dari rumah atau Work From Home (WFH). Orang tua yang bekerja dari rumah inilah yang diharapkan mampu dan bersedia mendampingi anak dalam proses pembelajaran.

Pendidikan pada abad 21 ini secara umum mewajibkan peserta didik menjadi generasi yang kedepannya sebagai individu yang kompetitif terhadap kemajuan zaman. Kurikulum 2013 menerapkan pembelajaran yang mengharuskan para pendidik menggunakan model-model pembelajaran yang sesuai terhadap perkembangan zaman. Belajar tidak hanya sekedar menghafal dan memahami materi saja, melainkan harus berimprovisasi ke arah keterampilan pengaplikasian yang diperoleh dari materi. Model pembelajaran yang diterapkan haruslah metode yang dapat menjadikan proses belajar yang efektif dan efisien, serta diharapkan mampu memompa motivasi peserta didik untuk selalu meningkatkan kualitas hasil belajarnya. Salah satu dari sekian banyak model pembelajaran yang ada adalah Project Based Learning (PjBL).

Menurut Cocco, dalam Kokotsaki et al., (2016) berpendapat bahwa Project Based Learning adalah salah satu model pembelajaran yang memusatkan pembelajaran kepada peserta didik atas tiga prinsip dasar yang konstruktivis: (1) pembelajaran merupakan konteks-spesifik, (2) keaktifan peserta didik dalam pembelajaran, dan (3) peserta didik dapat mencapai tujuan pembelajaran lewat interaksi sosial, berbagi pengetahuan serta pemahaman. Artinya aktivitas pembelajaran yang dilakukan haruslah mengulik proses pendapatan pengetahuan dan proses pengembangan keterampilan yang bertumpu pada keaktifan murid itu 
sendiri. Terlaksananya proses pembelajaran berbasis proyek ini diharapkan mampu mengeluarkan potensi yang ada dalam diri peserta didik. Model yang digunakan oleh seorang pendidik haruslah memperhatikan situasi dan kondisi terhadap peserta didik itu sendiri. Berdasarkan penelitian yang dilakukan oleh Amini(2015) mengungkapkan bahwa hasil belajar yang berpengaruh sangat tinggi saat menerapkan Project Based Learning. Kemudian Muzria \& Indrawati(2020) juga menemukan kelebihan terhadap penggunaan model Project Based Learning membawa pengaruh yang signifikan terhadap hasil belajar di sekolah dasar.

Pendampingan orang tua terhadap anaknya yang melaksanakan proses Belajar Dari Rumah (BDR) menjadi suatu kesempatan untuk mereka meningkatkan kerja sama satu sama lain, dan juga menjadi motivasi belajar bagi anak untuk melaksanakan pembelajaran. Hadirnya orang tua di sisi sang anak dalam Belajar Dari Rumah (BDR) mampu menjadi pengganti pendidik di sekolah. Hal tersebut sejalan dengan penelitian dari Lilawati(2020) yang menyatakan bahwa pembelajaran di rumah menjadi suatu upaya peningkatan jalinan keluarga antara orang tua dan anak. Peran orangtua di rumah menggantikan tugas guru di sekolah seperti pelaksana pembelajaran dan menjadi motivator untuk anak. Kemudian pendapat selanjutnya dikemukakan oleh Cahyati \& Kusumah(2020) bahwa belajar dari rumah juga menjadi peningkatan kelekatan antara orangtua dan anak, sehingga kemampuan anak dapat dipahami lebih dalam oleh orangtua. Perihal tersebut menjadi acuan bahwa orang tua memainkan peran penting selama kegiatan pembelajaran di rumah, sebab orangtua adalah madrasah pertama bagi sang anak sebelum memasuki jenjang persekolahan.

Terurainya beberapa permasalahan dan permasalahan di atas mengenai model pembelajaran Project Based Learning dan motivasi belajar hingga kerja sama antara orang tua dan anak menjadi satu konsentrasi penelitian kali ini. Pelaksanaan pembelajaran secara daring atau lebih dikenal dengan istilah Belajar Dari Rumah (BDR) ini mengharuskan orang tua aktif dalam mendampingi anaknya belajar. Selanjutnya penerapan Project Based Learning (PjBL) mengharuskan anak menjadi pusat pembelajaran untuk mengeksplorasi tentang materi yang dipelajari lebih dalam. Pembelajaran dalam konteks proyek ini pada dasarnya akan menjadikan anak yang belajar menjadi lebih dekat pada orang tuanya, sebab pendampingan orang tua terhadap anak yang membuat suatu proyek sebagai hasil belajarnya. Selain hal tersebut motivasi belajar untuk sang anak juga akan meningkat sebab orang tua memposisikan dirinya menjadi guru di sisi sang anak.

\section{METODE PENELITIAN}

Penelitian yang dilaksanakan sekarang ini merupakan jenis penelitian kualitatif, penelitian kualitatif adalah serangkaian penelitian yang menyajikan hasil data berbentuk deskripsi atas kata-kata tertulis atau lisan dari objek yang diamati (Hasnunidah, 2017). Kemudian menjabarkan hasil penelitian menggunakan metode deskriptif, rancangan penelitian metode deskriptif ini digunakan agar tujuan mendeskripsikan serta menjelaskan data yang diperoleh menjadi teks naratif yang mudah dibaca. Sasaran penelitian yang ditentukan adalah orang tua dan peserta didik kelas 4C SDN Grogol Utara 16 Jakarta Selatan.

Teknik pengumpulan data yang dilakukan adalah pengisian angket kuesioner yang disusun pada aplikasi google form yang disebarkan melalui aplikasi whatsapp pada tanggal 17 Juli 2021. Data utama yang didapatkan adalah sebanyak 25 responden orang tua dan 19 responden peserta didik. Kemudian data sekunder diperoleh dari studi kepustakaan seperti buku referensi dan jurnal atau artikel terkait. Setelah itu data yang telah diperoleh kemudian dianalisis menggunakan teknik milik Miles dan Huberman yaitu: (1) reduksi data, (2) penyajian data, dan (3) penarikan kesimpulan (Shidiq \& Choiri, 2019).

\section{HASIL DAN PEMBAHASAN PENELITIAN}

Pendidikan saat ini sedang dalam kondisi yang mengalami perubahan sistem pembelajaran. Dewi(2020) mengungkapkan bahwa Covid-19 memiliki dampak terbesar bagi pendidikan, sebab untuk memutus rantai 
penularan pandemi Covid-19 pembelajaran konvensional seperti di sekolah telah berubah menjadi belajar dari rumah dengan memanfaatkan beragam aplikasi. Selanjutnya menurut Arifa(2020) proses Belajar Dari Rumah (BDR) memiliki ideal tersendiri yaitu tetap dapat memfasilitasi kebutuhan belajar bagi peserta didik agar bisa dikembangkan minat dan bakatnya sesuai tingkat pendidikannya. Maka dalam mewujudkan hal itu perlunya kesiapan dari pendidik, penyesuaian kurikulum, penyediaan sumber belajar, hingga dukungan gawai serta jaringan yang stabil agar komunikasi dua arah antara pendidik terhadap peserta didiknya berlangsung efektif. Itulah sebabnya proses Belajar Dari Rumah (BDR) ini diperlukan banyaknya perhatian dari berbagai pihak, khususnya bagi para orang tua. Keadaan yang menyebabkan berubahnya pembelajaran tatap muka langsung dengan guru menjadi pembelajaran yang dilakukan secara mandiri di rumah harus mendapatkan perhatian berlebih dari setiap orang tua peserta didik. Berdasarkan hasil yang diperoleh dari pengisian angket kuesioner lewat google form ini terdapat 25 responden orang tua peserta didik dan 19 responden peserta didik yang akan disajikan dalam sub pembahasan berikut

\section{Kesediaan Orang Tua Mendampingi Proses Pembelajaran}

Penyajian data dalam sub pembahasan ini mengacu pada hasil kuesioner yang didapat. Berdasarkan data, orang tua yang bekerja dari rumah hanya 44\%, yaitu 14 dari 25 jawaban. Kemudian didukung oleh responden peserta didik yang mengatakan bahwa orang tuanya bekerja dari rumah hanya 36,8\%, yaitu 7 dari 19 jawaban.

Apakah anda bekerja dari rumah?

25 jasentan
Apakah mereka juga bekerja dari rumah?

19 juwaban
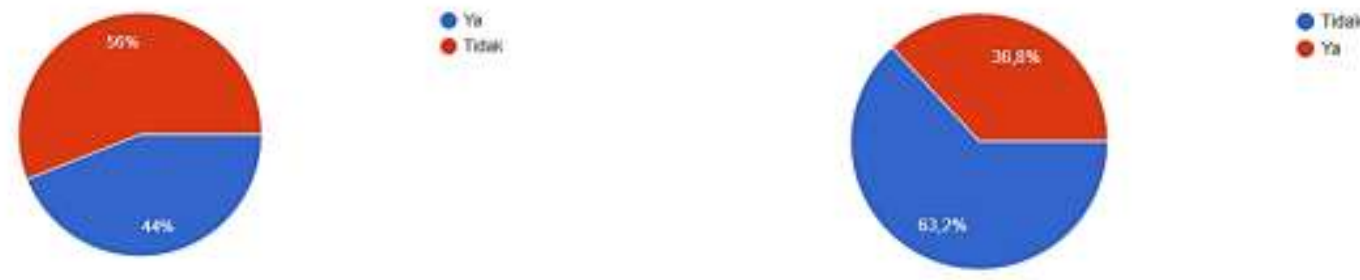

Gambar 1. Persentase orang tua yang Bekerja Dari Rumah

Hal tersebut mendapatkan pengaruh besar dalam penelitian kali ini, sebab ternyata tidak semua orang tua mampu mendampingi anaknya dalam melakukan kegiatan Belajar Dari Rumah (BDR) karena pekerjaan mereka tidak dilakukan di rumah. Penyebabnya adalah responden merupakan para pekerja sektor esensial yang mana dalam kebijakan pemerintah merupakan sektor pekerjaan yang harus dilakukan secara langsung. Melalui hal inilah ditemukan bahwasanya setiap orang tua tidak selalu mendampingi anaknya dalam melakukan kegiatan pembelajaran dari rumah. Sesuai dengan data sebagai berikut ini yang diperoleh hanya sebanyak 60\% atau setara 15 dari 25 jawaban yang selalu mendampingi anaknya belajar dari rumah. Kemudian didukung oleh hasil data responden peserta didik yang menjawab sebanyak 84,2\%, yaitu 16 orang saja yang didampingi oleh orang tuanya belajar dari rumah. 
Seberapa sering andis mendampingi putrajputri anda melsesarskas kegis!an Belijar Dari Rumah (BDR) dari sehoish of rumah?

ISimatesn

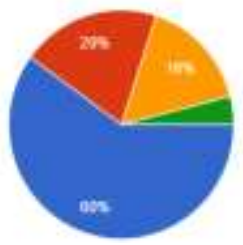

Apakah orang tua karru mendampingi kamu saat Belajar Dari Rurnah (BOR)? in jawaben

Gambar 2. Persentase orang tua yang mendampingi anaknya belajar dari rumah.

Meskipun pada data terlihat orang tua yang bisa mendampingi anaknya hanya beberapa persen, namun mereka yang belum sempat mendampingi anaknya saat berlangungnya proses Belajar Dari Rumah (BDR) itu digantikan oleh keluarga yang lain, misalnya kakak. Tentunya orang tua yang tidak bisa mendampingi anaknya pasti memiliki alasan tersendiri. Para orang tua yang tidak bekerja secara daring di rumah maupun bekerja secara daring di rumah bisa menghabiskan waktunya bekerja selama lebih dari 8 jam (Gambar 3). Oleh karena itu banyak yang tidak bisa membantu anaknya, bahkan mereka yang membantu anaknya melakukan pembelajaran BDR ini juga merasa terganggu. Sebanyak 56\% orang tua yang merasa terganggu karena mendampingi anaknya (Gambar 3) BDR juga karena disebabkan oleh mereka yang membantu anaknya BDR masih melangsungkan pekerjaan mereka, dilihat dari data ada $68 \%$ orang tua yang belum menyelesaikan pekerjaannya.

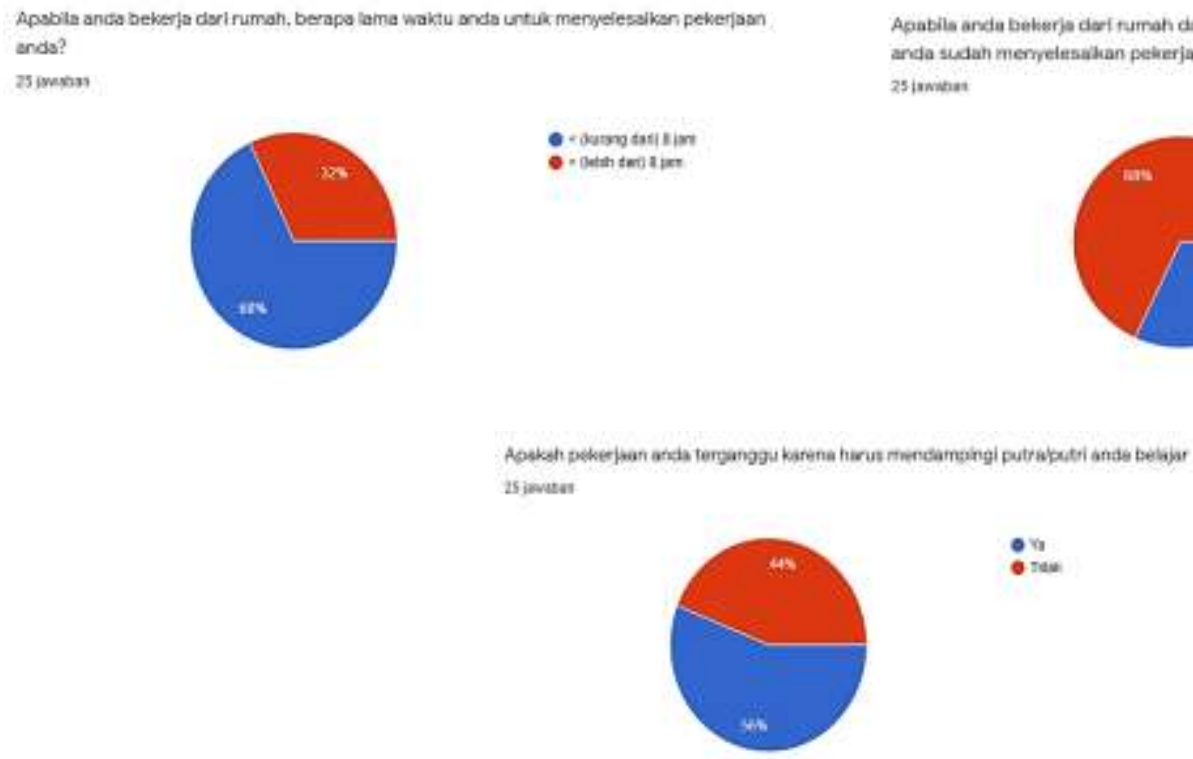

Gambar 3. Persentase waktu orang tua bekerja, dan gambaran orang tua yang membantu anaknya BDR saat melakukan pekerjaan.

Dilihat dari hasil yang diperoleh ini ternyata masih banyak orang tua yang kesediaannya dalam membantu anaknya melakukan kegiatan Belajar Dari Rumah (BDR) ini terhalang oleh pekerjaan mereka. Tak bisa dipungkiri bahwasanya tidak semua orang tua yang bekerja dari rumah juga bisa mendampingi anaknya, sebab harus melakukan pekerjaan rumah yang lainnya. Oleh karena itu adanya fleksibilitas dari para pendidik untuk memberikan kelonggaran kepada mereka yang belum melaksanakan pembelajaran agar bisa dilakukan setelah orang tua senggang, misalnya pada saat malam hari, orang tua yang sudah selesai melakukan pekerjaannya mendampingi anak untuk melakukan pembelajaran. Hal ini sejalan dengan penelitian Revilda et 
al.(2021) yang menemukan dampak yang dirasakan selama BDR bagi para orang tua, cenderung merasa jenuh dan sulit dalam mendampingi anak melaksanakan pembelajaran, hal itu disebabkan waktu yang tidak sinkron antara orang tua yang bekerja dengan jadwal anak BDR, serta ada beberapa orang tua yang masih memiliki keterbatasan hingga tidak bisa memfasilitasi anaknya menerapkan BDR.

\section{Pembelajaran Project Based Learning dan Pengaruhnya}

Fokus pembahasan kali ini adalah bagaimana proses pembelajaran yang menggunakan model Project Based Learning dapat mempengaruhi motivasi belajar peserta didik dan juga kerja sama antara peserta didik dengan orang tuanya. Project Based Learning adalah salah satu pembelajaran yang memusatkan proses pembelajaran pada peserta didik (student centered), hingga pembelajaran yang bersifat efektif akan diperoleh sebab peserta didik menjelajahi lebih jauh sebuah materi yang dipelajari, bahkan peserta didik bisa menggunakan konteks sebuah proyek sebagai hasil belajarnya. Berdasarkan hal tersebut, data yang diperoleh kali ini adalah bagaimana situasi pembelajaran Project Based Learning dilakukan selama Belajar Dari Rumah (BDR) oleh para peserta didik. Situasi kelas kali ini ternyata jarang menerapkan model pembelajaran Project Based Learning, hal itu dibuktikan dengan pengisian angket dengan hasil jawaban yang tidak lebih dari $40 \%$ dari orang tua maupun peserta didik yang menjawab jarang melaksanakan proses pembelajaran dengan Project Based Learning

Seberapa sering putra/putri anda mendapatken tugas untuk membust proyek? 25 jamicen

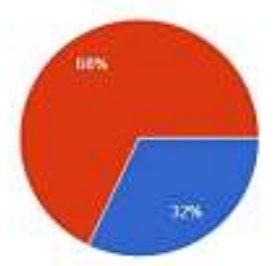

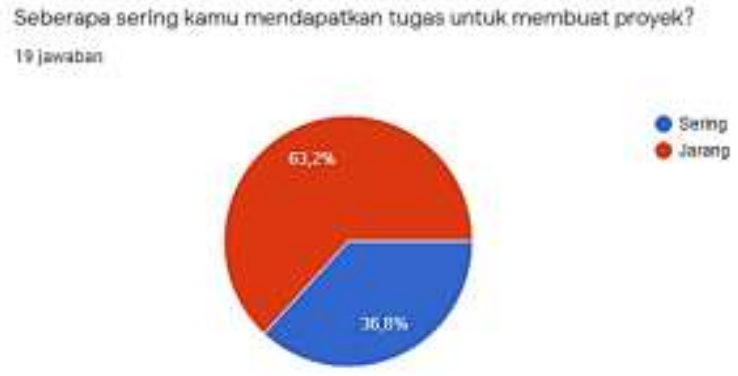

Seberapa sering kamu mendapatkan tuges untuk membuat proyek?

seing

Gambar 4. Persentase keseringan berlangsungnya proses pembelajaran PjBL

Proses pembelajaran PjBL ini yang dianggap jarang oleh orang tua maupun peserta didik menjadi suatu anggapan dari penulis bahwa data ini sangat mempengaruhi. Sebab frekuensi jarangnya penggunaan menjadi suatu ukuran dari kegunaan model PjBL ini terhadap pengaruh penelitian. Selanjutnya adalah dari penerapan Project Based Learning ini selama dalam proses pembelajarannya terlihat beberapa kali hasil belajar sesuai konteks sebuah proyek itu sendiri. Hal ini dibuktikan dengan hasil jawaban dari orang tua dan peserta didik mengenai hasil proyek dalam penerapan PjBL itu sendiri.

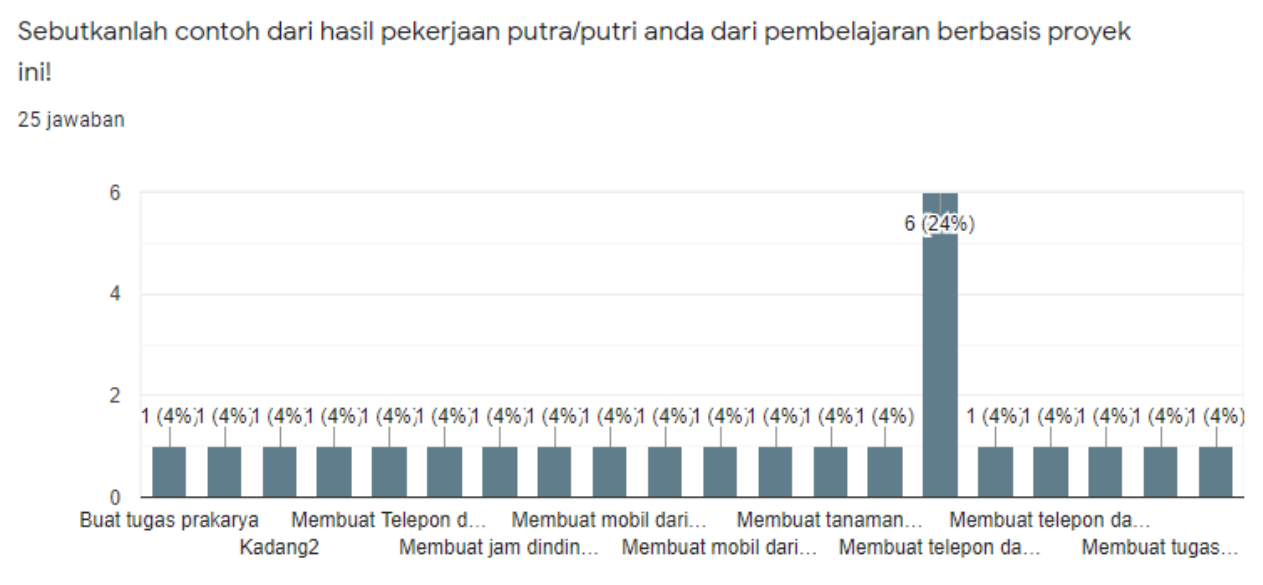

Gambar 5. Hasil proyek peserta didik dalam pembelajaran PjBL 
Jawaban ini memiliki keberagaman bentuk hasil belajar, hal ini karena dalam pengisian angket hanya dibutuhkan contohnya saja. Beberapa hasil jawaban yang dapat dirangkum adalah sebagai berikut, (1) hasil belajar membuat telepon dari bahan gelas plastik mendapat jawaban tertinggi dengan 10 jawaban, (2) hasil belajar membuat tanaman hias dan pohon dari bahan plastik memperoleh 5 jawaban, (3) membuat kerajinan dari bahan dasar kardus seperti mobil dan jam dinding memperoleh 3 jawaban, (4) membuat kerajinan pesawat terbang dari bahan dasar botol plastik ada 2 jawaban, dan (5) membuat bentuk seni rupa dari bahan dasar sabun ada 1 jawaban. Sisanya adalah jawaban yang dirasa tidak mewakilkan dari hasil pertanyaan yang tertera. Berdasarkan hasil dari data ini, maka PjBL menuntut siswa untuk terus berkreasi dan berinovasi mengenai materi yang diajarkan. Sejalan dengan hal ini, Nugroho et al.(2019) menemukan hasil penelitian bahwa model pembelajaran Project Based Learning berpotensi menaikkan kompetensi peserta didik agar dapat berpikir kreatif. Saat menjalani proses pembelajaran peserta didik lebih aktif, terlebih mereka terlatih dalam berdiskusi untuk beropini, memberikan solusi serta menyelesaikan permasalahan dari perspektif lain dalam konteks pembuatan proyek yang menghasilkan produk.

Pelaksanaan pembelajaran dari rumah hendaknya memerlukan kontribusi dari orang tua, sebab kehadiran seorang pendidik yang biasanya bertatap muka di sekolah kini hanya melalui aplikasi daring semata. Untuk itu diperlukan peran pengganti seorang pendidik di rumah. Menurut Agung Nugroho et al.(2021) dalam melaksanakan proses pembelajaran di rumah, orang tua dalam peranannya terhadap menggantikan sosok guru memiliki 3 hal kontribusi, yaitu (1) sebagai pendamping anak saat belajar di rumah, (2) menjadi fasilitator, dan (3) sebagai seorang motivator dan juga director atau pengarah. Meninjau sebuah pernyataan tersebut ditemukanlah data yang sesuai sebagai berikut.

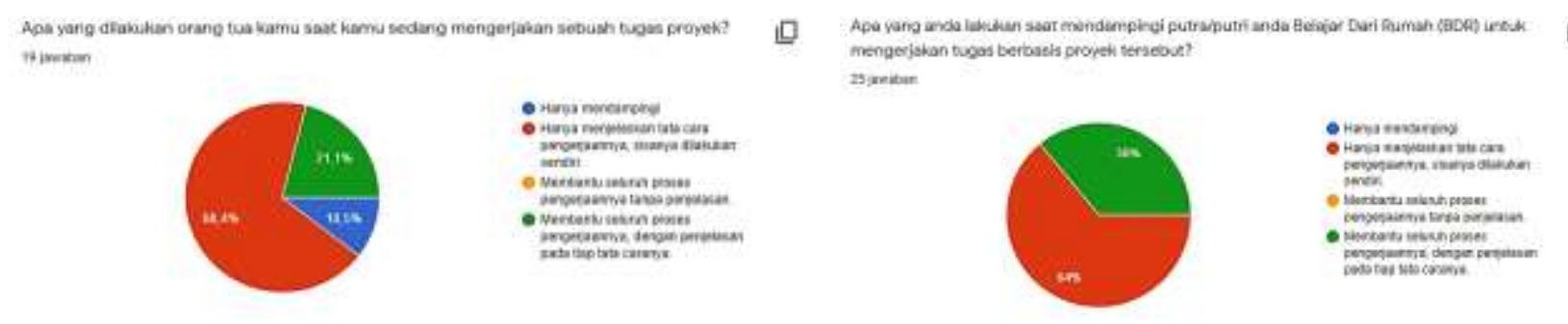

Gambar 6. Kontribusi orang tua dalam mendampingi anak BDR

Berdasarkan gambar di atas diperoleh data bahwa orang tua yang mendampingi anaknya rata-rata hanya memberikan penjelasan atau tata cara dari pengerjaan tugas yang diberikan dalam pembuatan produk dalam sebuah proyek. Kontribusi para orang tua dalam mendampingi anaknya melakukan pembelajaran secara daring ini ternyata dirasakan oleh setiap anak-anaknya. Setiap peserta didik yang didampingi dan dibantu dalam pengerjaannya merasa mengalami perbedaan saat didampingi dan saat melakukannya secara mandiri. Peserta didik yang melakukan pengerjaan proyek secara mandiri cenderung tidak merasa bersemangat dalam mengerjakannya, hal ini dibuktikan dengan data kuesioner peserta didik yang hanya 47,4\% menjawab rajin dalam pengerjaan secara mandiri, kemudian orang tua hanya $52 \%$ yang menjawab anaknya rajin saat bekerja secara mandiri sebagai berikut. 
Merurut kamu apa yang kermu rasskan saat hans menger jakan tugas propek secara mender?

18 moven

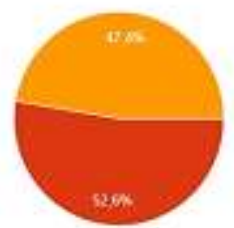

Menurut anda. bagaimanu mothesi belajar dari putrafputri anda sast proses penoepiaan gropenk pecara mandiri

25 imaton

Gambar 7. Motivasi belajar bagi peserta didik saat melakukan BDR secara mandiri

Motivasi belajar peserta didik saat bekerja secara mandiri cenderung tidak semangat adalah karena mereka mungkin tidak memahami materi yang dipelajari, kemudian ada hal-hal seperti tata cara pengerjaan, bentuk pekerjaan atau hal apapun yang menyangkut selama proses pembelajaran itu. Sejalan dengan temuan Firmansyah(2021) bahwa setiap proses kegiatan Belajar Dari Rumah tidak sempurnanya fase pemerolehan perhatian dari peserta didik sebab materi pembelajaran dan pengalaman belajar peserta didik belum relevan. Berbeda dengan saat didampingi oleh orang tua, peserta didik merasa sangat senang dan antusias dalam melaksanakan atau mengerjakan proses pembelajaran proyek ini. Hal tersebut terbukti dalam data yang diperoleh dari kuesioner, dimana para siswa menjawab senang sebanyak $89,5 \%$, dan orang tua yang berpikir bahwa anaknya antusias saat didampingi melakukan BDR sebanyak $72 \%$.

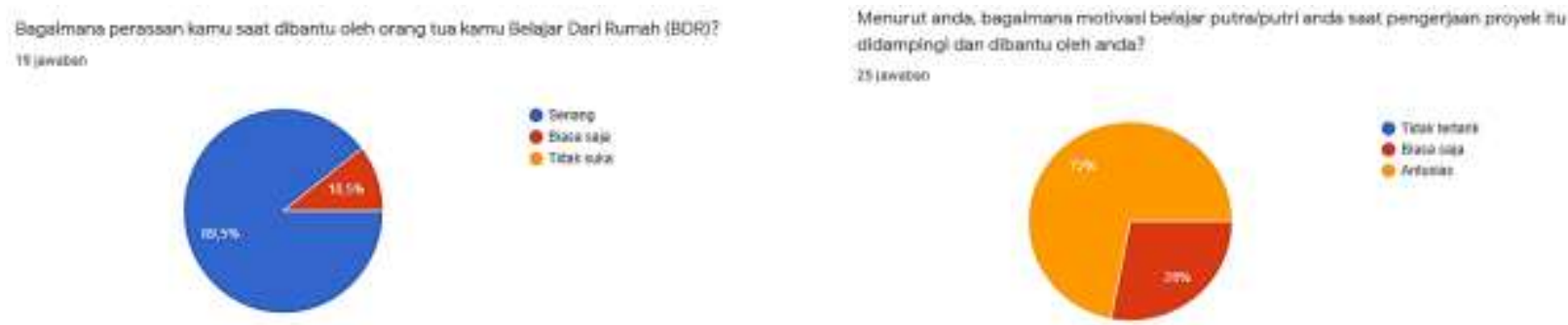

Gambar 8. Motivasi belajar peserta didik saat melakukan BDR didampingi orang tua

Berdasarkan kedua data yang diperoleh dari gambar 7 dan gambar 8 maka pengaruh pembelajaran berbasis proyek ini terhadap peningkatan motivasi belajar anak, dan seiring dengan hal itu peran orang tua juga sangat penting dalam meningkatnya motivasi belajar ini. Hal tersebut karena orang tua memberikan kontribusi dalam pembelajaran sang anak dengan memberikan motivasi dan mengarahkan cara kerja anak dengan cara menjelaskan tentang apa yang terkandung dari materi yang dipelajari.
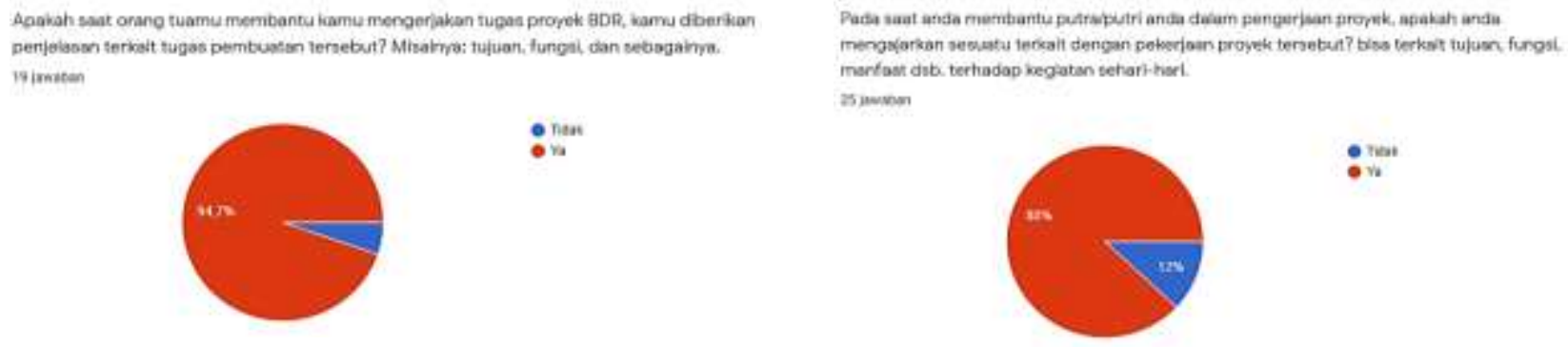

Gambar 9. Peran orang tua menjadi motivator dan pengarah peserta didik

Peran orang tua dalam mendampingi peserta didik membawa pengaruh tersendiri bagi mereka. Kehadiran orang tua di sisi peserta didik menggantikan pendidik untuk mengajarkan, mengarahkan dan memberikan motivasi menjadi suatu bentuk kelekatan mereka dalam berkeluarga. Apalagi perlu ditekankan disini bahwa pembelajaran yang berlangsung menggunakan model Project Based Learning, yang biasanya membuatkan hasil belajar peserta didik itu berbentuk produk. Kerja sama antara orang tua dan peserta didik 
disini menjadi meningkat, sebab peserta didik mendapatkan pendampingan berupa bantuan pembuatan, penjelasan tata cara pengerjaan dan bahkan hingga motivasi yang diperoleh berdasarkan materi yang dipelajari. Kerja sama ini dibuktikan dengan data dimana setelah berlangsungnya pembuatan produk dari sebuah pembelajaran berbasis proyek ini dari mereka di rumah. Banyak hal yang mereka hasilkan dari kerja sama mereka yang dibuktikan dari hal berikut.

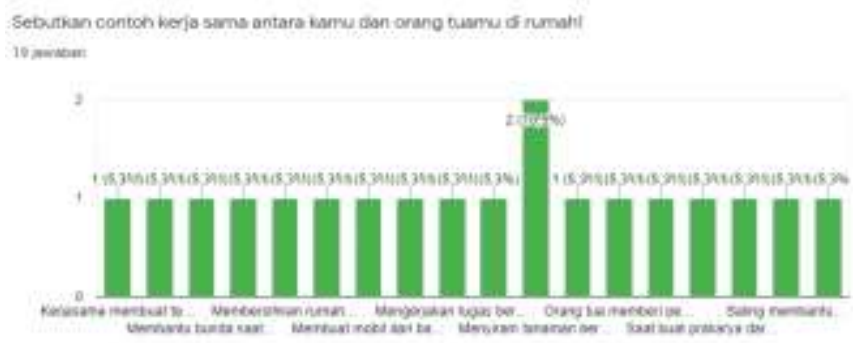

Gambar 10. Bentuk kerja sama yang dihasilkan antara orang tua dan peserta didik di rumah.

Keberhasilan peningkatan kerja sama antara orang tua dan peserta didik di rumah dapat terlihat dari bentuk kerja sama antara orang tua dan anak (Gambar 10). Bentuk-bentuk kerja sama itu tidak lepas dari pengaruh suatu model pembelajaran bernama Project Based Learning. Pembelajaran yang berpusat pada peserta didik ini menuntut siswa untuk terus aktif dan kreatif untuk menjawab persoalan dalam sebuah materi yang biasanya dihasilkan dalam bentuk produk. Hal tersebut sejalan dengan pendapat Putri et al.(2021) bahwa penerapan Project Based Learning memiliki keunggulan untuk memberi pengaruh hasil belajar peserta didik, sebab dalam pelaksanaannya PjBL dikatakan sebuah pembelajaran yang inovatif karena selain menyelesaikan persoalan dan mengelola pembelajaran dengan melibatkan pekerjaan proyek, mereka dituntun agar aktif dan menumbuhkan sikap-sikap yang positif, salah satunya kerja sama.

\section{KESIMPULAN}

Model pembelajaran Project Based Learning dalam penerapannya di situasi pandemi saat ini dimana semua sektor pendidikan menerapkan kegiatan Belajar Dari Rumah (BDR) membawa pengaruh signifikan bagi para orang tua dan peserta didik, khususnya kelas 4 SDN Grogol Utara 16 Jakarta Selatan. Pengaruh dari Project Based Learning ini dirasakan karena model PjBL yang menekankan pembelajaran terpusat pada siswa mengharuskan siswa untuk terus aktif dan inovatif dalam menyelesaikan persoalan-persoalan yang dapat mereka selesaikan dengan hasil sebuah produk dari bentuk kreativitas mereka melaksanakan pembelajaran proyek. Pembelajaran BDR ini peran orang tua menjadi peran sentral, sebab mereka menggantikan posisi seorang pendidik di sekolah. Penggantian peran ini menuntun orang tua untuk dapat mendampingi, mengajari dan memberikan motivasi untuk peserta didik dalam melaksanakan pembelajaran. Hal itu menjadi faktor utama dalam meningkatnya motivasi belajar peserta didik. Selain itu dengan pendampingan yang terus menerus dalam pembuatan produk sekaligus mempengaruhi peningkatan kelekatan antara peserta didik dengan orang tuanya yang dibuktikan dengan kerja sama mereka.

\section{DAFTAR PUSTAKA}

Amini, R. (2015). Pengaruh Penggunaan Project Based Learning Dan Motivasi Belajar Terhadap Hasil Belajar Siswa Kelas V Sd. Prosiding Seminar Nasional Pendidikan Biologi, 4(2007), 339-345. Https://Biology.Umm.Ac.Id/Files/File/571-576 Risda Amini.Pdf

Arifa, F. N. (2020). Tantangan Pelaksanaan Kebijakan Belajar Dari Rumah Dalam Masa Darurat Covid-19. Info Singkat;Kajian Singkat Terhadap Isu Aktual Dan Strategis, Xii(7/I), 6. Http://Berkas.Dpr.Go.Id/Puslit/Files/Info_Singkat/Info Singkat-Xii-7-I-P3di-April-2020-1953.Pdf 
3172 Pengaruh Model Pembelajaran Project Based Learning terhadap Peningkatan Motivasi Belajar dan Kerja Sama Siswa dan Orang Tua di Era Pandemi - Indradi Kartika Sukmana, Nur Amalia DOI: https://doi.org/10.31004/edukatif.v3i5.1068

Cahyati, N., \& Kusumah, R. (2020). Peran Orang Tua Dalam Menerapkan Pembelajaran Di Rumah Saat Pandemi Covid 19. Jurnal Golden Age, 4(01), 4-6. Https://Doi.Org/10.29408/Jga.V4i01.2203

Dewi, W. A. F. (2020). Dampak Covid-19 Terhadap Implementasi Pembelajaran Daring Di Sekolah Dasar. Edukatif: Jurnal Ilmu Pendidikan, 2(1), 55-61. Https://Doi.Org/10.31004/Edukatif.V2i1.89

Firmansyah. (2021). Motivasi Belajar Dan Respon Siswa Terhadap Online Learning Sebagai Strategi Pembelajaran Di Masa Pandemi Covid-19. Edukatif: Jurnal Ilmu Pendidikan, 3(2), 589-597. Https://Doi.Org/10.31004/Edukatif.V3i2.355

Hasnunidah, N. (2017). Metodologi Penelitian Pendidikan (1st Ed.). Media Akademi.

Kokotsaki, D., Menzies, V., \& Wiggins, A. (2016). Projcet Based Learning: A Review Of The Literature. Improving Schools, 19(3), 267-277. Https://Doi.Org/Https://Doi.Org/10.1177\%2f1365480216659733

Lilawati, A. (2020). Peran Orang Tua Dalam Mendukung Kegiatan Pembelajaran Di Rumah Pada Masa Pandemi. Jurnal Obsesi: Jurnal Pendidikan Anak Usia Dini, 5(1), 549. Https://Doi.Org/10.31004/Obsesi.V5i1.630

Muzria, W., \& Indrawati, T. (2020). Pengaruh Model Project Based Learning (Pjbl) Terhadap Hasil Belajar Siswa Di Sekolah Dasar. Jurnal Basicedu, 4(3), 2232-2238. Https://Doi.Org/10.31004/Basicedu.V5i1.684

Nugroho, Agung, Hawanti, S., \& Pamungkas, B. T. (2021). Kontribusi Orang Tua Dalam Pendampingan Belajar Siswa Selama Masa Pandemi. Jurnal Basicedu, 5(4), 1691-1699. Https://Doi.Org/Https://Doi.Org/10.31004/Basicedu.V5i4.969

Nugroho, Andri Tri, Jalmo, T., \& Surbakti, A. (2019). Pengaruh Model Project Based Learning (Pjbl) Terhadap Kemampuan Komunikasi Sains Dan Berpikir Kreatif. Journal Bioterdidik, 7(3), 50-58.

Putri, F. P. W., Koeswanti, H. D., \& Giarti, S. (2021). Perbedaan Model Problem Based Learning Dan Project Based Learning Terhadap Hasil Belajar Siswa Sekolah Dasar. Edukatif : Jurnal Ilmu Pendidikan, 3(2), 496-504. Https://Doi.Org/10.31004/Edukatif.V3i2.356

Revilda, E., Hadi, N., \& Purwasih, J. H. G. (2021). Dampak Belajar Dari Rumah. Naturalistic : Jurnal Kajian $\begin{array}{llll}\text { Penelitian Pendidikan Dan 822-832. } & \text { 8 }\end{array}$ Https://Doi.Org/10.35568/Naturalistic.V5i2.1133

Shidiq, U., \& Choiri, M. M. (2019). Metode Penelitian Kualitatif Di Bidang Pendidikan. In A. Mujahidin (Ed.), Journal Of Chemical Information And Modeling (1st Ed., Vol. 53, Issue 9). Nata Karya. Http://Repository.Iainponorogo.Ac.Id/484/1/Metode Penelitian Kualitatif Di Bidang Pendidikan.Pdf 